\title{
Characterization of the positive and negative inotropic effects of acetylcholine in the human myocardium
}

\author{
Xiao Y. Du a , Regien G. Schoemaker ${ }^{\text {a }}$, Egbert Bos ${ }^{\text {b }}$, Pramod R. Saxena ${ }^{\text {a, } *}$

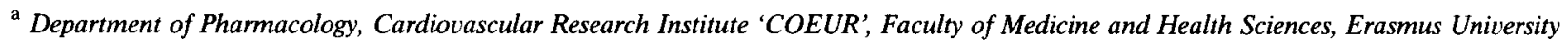 \\ Rotterdam, P.O. Box 1738, 3000 DR Rotterdam, Netherlands \\ ${ }^{\mathrm{b}}$ Department of Thoracic Surgery, Cardiovascular Research Institute 'COEUR', Faculty of Medicine and Health Sciences, Erasmus University \\ Rotterdam, P.O. Box 1738, 3000 DR Rotterdam, Netherlands
}

Received 9 February 1995; revised 20 April 1995; accepted 20 June 1995

\begin{abstract}
In the human isolated myocardium, acetylcholine $\left(10^{-9}\right.$ to $10^{-3} \mathrm{M}$ ) elicited a biphasic inotropic effect (a decrease in the lower and an increase in the higher concentration range) in atrial and a positive inotropic effect in ventricular trabeculae. However, under conditions of raised contractility achieved by exposure to noradrenaline $\left(10^{-5} \mathrm{M}\right)$, only negative inotropic effects were observed in both atria and ventricles. Atropine $\left(10^{-6} \mathrm{M}\right)$, but not propranolol $\left(10^{-6} \mathrm{M}\right)$, antagonized both positive and negative inotropic effects of acetylcholine, thus showing that the responses were mediated by muscarinic acetylcholine receptors. The use of subtype selective muscarinic receptor antagonists $\left(10^{-7}\right.$ to $\left.10^{-5} \mathrm{M}\right)$, pirenzepine $\left(\mathrm{M}_{1}>\mathrm{M}_{3}>\mathrm{M}_{2}\right)$, AF-DX 116 (11-(\{2-[(diethylamino)-methyl]-1-piperidyl\}acetyl)-5,11-dihydro-6 $H$-pyridol[2,3-b][1,4]benzodiazepine-6-one base; $\mathbf{M}_{2}>\mathbf{M}_{1}>\mathbf{M}_{3}$ ) and HHSiD ( $p$-fluorohexahydro-siladifenidol hydrochloride; $\mathbf{M}_{3} \geq \mathbf{M}_{1} \gg \mathbf{M}_{2}$ ) revealed that the negative inotropic effect of acetylcholine in atrial as well as the positive inotropic effect in ventricular trabeculae were best antagonized by AF-DX 116 and not by pirenzepine, suggesting the involvement of the muscarinic $\mathbf{M}_{2}$ receptor subtype, possibly linked to different second messenger systems. On the other hand, the positive inotropic effect of acetylcholine $\left(10^{-6}\right.$ to $\left.10^{-3} \mathrm{M}\right)$ in the atrial tissue, observed only in preparation with depressed contractility, was not effectively antagonized by either AF-DX 116 or HHSiD, but was significantly reduced by pirenzepine. Furthermore, the selective muscarinic $\mathrm{M}_{1}$ receptor agonist McN-A-343 (4- $(m-\mathrm{chloro}-$ phenylcarbamoyloxy)-2-butynyltrimethyl ammonium chloride; $10^{-9}$ to $10^{-3} \mathrm{M}$ ), which failed to significantly change the baseline contractility in either atrial or ventricular trabeculae, produced a positive inotropic effect in atrial preparations when contractility had been depressed by prior treatment with acetylcholine $\left(10^{-9}\right.$ to $\left.10^{-7} \mathrm{M}\right)$. This effect of $\mathrm{McN}$ - A-343 was effectively antagonized by pirenzepine $\left(10^{-5} \mathrm{M}\right)$. These data show that, besides the muscarinic $\mathrm{M}_{2}$ receptor mediating both negative (atria) and positive (ventricle) inotropic effects, muscarinic $M_{1}$ receptors, capable of reversing depressed atrial contractility, are present in the human heart.
\end{abstract}

Keywords: Acetylcholine; Atrium AF-DX 116, human; HHSiD ( $p$-fluorohexahydro-siladifenidol hydrochloride); McN-A-343; Muscarinic receptor; Myocardial contractility; Pirenzepine; Ventricle

\section{Introduction}

It is well known that acetylcholine causes negative inotropic and chronotropic effects in the mammalian heart, including humans (Brodde et al., 1992; Caulfield, 1993; Böhm et al., 1994; Landzberg et al., 1994). In addition, studies have shown that acetylcholine can

\footnotetext{
${ }^{*}$ Corresponding author. Tel. (31) (0)10-408 7537/47, fax (31) (0)10-436 6389, e-mail SAXENA@FARMA.FGG.EUR.NL.
}

elicit a positive inotropic response in isolated cardiac tissue of some species (Endoh and Blinks, 1984; Tajima et al., 1987; Eglen et al., 1988). In our previous study in the human isolated myocardium, we reported that acetylcholine elicited a biphasic response (an initial decrease followed by an increase in contractility back to baseline values) in the atrial trabeculae, whereas only a positive inotropic effect was noticed in the ventricular trabeculae ( $\mathrm{Du}$ et al., 1994). This latter effect was not observed earlier (Jakob et al., 1989; Deighton et al., 1990; Böhm et al., 1994). 
Five muscarinic acetylcholine receptor subtype genes have been cloned and expressed, but only muscarinic $\mathbf{M}_{2}$ receptors have been detected in the human heart (Maeda et al., 1988; Ford et al., 1992; Caulfield, 1993). Correspondingly, the responses to muscarinic receptor agonists in the cardiac muscle appear to be mediated by the activation of well-characterized muscarinic $\mathbf{M}_{2}$ receptors, which are coupled to different signal transduction pathways (Schimerlik, 1989). However, the cardiac effects of muscarinic receptor stimulation are not yet fully understood and evidence is emerging that, besides the muscarinic $\mathrm{M}_{2}$ receptor, other muscarinic receptor subtypes are also expressed in the heart. For example, the muscarinic $M_{1}$ receptor seems to mediate positive inotropic effects in cells isolated from adult guinea-pig ventricles (Gallo et al., 1993) as well as the increase in automaticity in canine Purkinje fibres (Rosen et al., 1990). Furthermore, it has been reported that low doses of pirenzepine $(<3 \mathrm{mg}$ ) cause bradycardia that coincides with the blockade of muscarinic $M_{1}$ receptors in humans (Pitschner and Wellstein, 1988). Thus, it is suggested that although the predominant population of muscarinic receptors at postsynaptic sites in the heart is of the $\mathrm{M}_{2}$ subtype, a small population of $M_{1}$ subtype is also present (Watson et al., 1983; Evans et al., 1985).

The purpose of the present study was to characterize the receptors involved in the observed inotropic effects of acetylcholine in the human cardiac tissue (Du et al., 1994) by using relatively selective antagonists at the muscarinic $\mathrm{M}_{1}, \mathrm{M}_{2}$ or $\mathrm{M}_{3}$ receptors (Doods et al., 1987) as well as a selective agonist at the muscarinic $M_{1}$ receptor. A part of this investigation has been presented at the last winter meeting of the British Pharmacological Society (Du et al., 1995).

\section{Material and methods}

\subsection{Preparations}

Right atrial and left ventricular trabeculae were obtained from 61 heart beating organ donors (43 males, 18 females aged 2-55 years), who died of non-cardiac disorders ( 36 cerebrovascular accident, 20 polytrauma, 5 hypoxia) less than $24 \mathrm{~h}$ before the tissue was brought to the laboratory. The hearts were kindly provided by the Rotterdam Heart Valve Bank (Bio Implant Services Foundation/Eurotransplant Foundation) after removal of the aortic and pulmonary valves for homograft valve implantation. The hearts were stored at $0-4^{\circ} \mathrm{C}$ in a sterile organ protecting solution (UW, Eurocollins, or HTK-Brettschneider, see Ploeg et al., 1992) immediately following circulatory arrest. After excision, tissue samples were placed in ice-chilled oxygenated Krebs buffer (composition in $\mathrm{Mm}$ : $\mathrm{NaCl} 118$,
$\mathrm{KCl} 4.7, \mathrm{CaCl}_{2}$ 2.5, $\mathrm{MgSO}_{4}$ 1.2, $\mathrm{NaHCO}_{3} 25, \mathrm{KHPO}_{4}$ 1.2 and glucose 8.3) and atrial and ventricular trabeculae ( $<1 \mathrm{~mm}$ thickness) were carefully dissected free. The trabeculae were mounted in organ baths containing $\mathrm{Krebs}$ buffer $\left(37^{\circ} \mathrm{C}\right.$, gassed with $95 \% \mathrm{O}_{2}$ and $5 \%$ $\mathrm{CO}_{2}$ ) and paced at $1 \mathrm{~Hz}$ using electrical field stimulation ( $3 \mathrm{~ms}$, voltage $20 \%$ above threshold). The developed tension was recorded using isometric Harvard transducers and Goerz flatbed recorders (Schoemaker et al., 1993; Du et al., 1994). Based on preliminary experiments, the chosen optimal resting load, yielding the highest developed tension, was $750 \mathrm{mg}$ and 1950 mg for atrial and ventricular trabeculae, respectively.

\subsection{Experimental protocol}

After stabilization, the resting tension and baseline contractile force were measured. A concentration-response curve for noradrenaline was obtained to check the viability of the tissues (Schoemaker et al., 1993; Du et al., 1994). Tissues with less than $25 \mathrm{mg}$ response to $10^{-5} \mathrm{M}$ noradrenaline were excluded from further analysis.

After washing (6 times) and stabilization, $10^{-6} \mathrm{M}$ physostigmine was added to the Krebs buffer in experiments involving acetylcholine to prevent its rapid degradation by cholinesterase (see Chatonnet and Lockridge, 1989). One cumulative concentration-response curve for acetylcholine $\left(10^{-9}\right.$ to $\left.10^{-3} \mathrm{M}\right)$ was constructed in each atrial and ventricular preparation, in the absence (control) or after $\mathbf{3 0} \mathrm{min}$ incubation with one of the following antagonists: propranolol $\left(10^{-6} \mathrm{M}\right.$, non-selective $\beta$-adrenoceptor antagonist), atropine $\left(10^{-6} \mathrm{M}\right.$, non-selective muscarinic receptor antagonist), pirenzepine $\left(10^{-7}, 10^{-6}\right.$ or $10^{-5} \mathrm{M}$, muscarinic $\mathrm{M}_{1}$ receptor antagonist, Hammer et al., 1980), AF-DX 116 $\left(10^{-7}, 10^{-6}\right.$ or $10^{-5} \mathrm{M}$, muscarinic $\mathrm{M}_{2}$ receptor antagonist, Giachetti et al., 1986) and HHSiD $\left(10^{-6}\right.$ or $10^{-5}$ $M$, muscarinic $\mathbf{M}_{3}$ receptor antagonist, Lambrecht et al., 1989). In addition, the effects of acetylcholine on trabeculae pre-stimulated with noradrenaline $\left(10^{-5} \mathrm{M}\right)$ were investigated either in the absence or presence of $10^{-6} \mathrm{M}$ atropine.

Since not all effects of acetylcholine could be fully explained after the use of antagonists, we also investigated the effects of a muscarinic $\mathbf{M}_{1}$ receptor agonist, $\mathrm{McN}-\mathrm{A}-343$. One cumulative concentration-response curve for $\mathrm{McN}-\mathrm{A}-343\left(10^{-9}\right.$ to $\left.10^{-3} \mathrm{M}\right)$ was obtained in each atrial and ventricular preparation. In addition, in the atrial tissue, cumulative concentration-response curves for $\mathrm{McN}-\mathrm{A}-343\left(10^{-9}\right.$ to $\left.10^{-3} \mathrm{M}\right)$ were also constructed following a maximal negative inotropic effect induced by acetylcholine $\left(10^{-9}\right.$ to $\left.\geq 10^{-6} \mathrm{M}\right)$, in the absence or presence of pirenzepine $\left(10^{-5} \mathrm{M}\right)$.

There was no apparent difference in the responses to noradrenaline or acetylcholine observed in trabecu- 
lae obtained from subjects of different age or dying from different causes. This is also true for a number of other subtances, including 5-hydroxytryptamine and histamine (Schoemaker et al., 1993; Du et al., 1993,1994).

\subsection{Data presentation and analysis}

Data are presented as means \pm S.E.M. Baseline values for atrial and ventricular tissue were compared using an unpaired $t$-test. The effects of acetylcholine and McN-A-343 in the absence or presence of various antagonists were analyzed using an analysis of variance for repeated measurements. Differences were regarded statistically significant, if $P \leq 0.05$. Since the negative inotropic response in atrial and the positive inotropic response in ventricular tissues reached their maximum, the curves were fitted to a four-parameter logistic function (De Lean et al., 1978) to calculate, where applicable, apparent $\mathrm{pD}_{2}$ values (negative logarithm of the molar concentration eliciting half-maximal effect). Apparent $\mathrm{p} K_{\mathrm{B}}$ values were derived from $\mathrm{pD}_{2}$ values, using the following equation: $\mathrm{p} K_{\mathrm{B}}=-\log [\mathrm{B}]+$ $\log \left\{\left(\left[\mathrm{A}_{2}\right] /\left[\mathrm{A}_{1}\right]\right)-1\right\}$, where $[\mathrm{B}]$ is the molar concentration of antagonists and $\left[A_{1}\right]$ and $\left[A_{2}\right]$ represent molar concentrations of agonists eliciting half-maximal effect in the absence and presence of antagonists, respectively.

\subsection{Chemicals used}

The chemicals used in the present study were: acetylcholine chloride (Ciba, Breda, Netherlands), AFDX 116 (11-(\{2-[(diethylamino)-methyl]-1-piperidyl $\}$ acetyl)-5,11-dihydro- $6 H$-pyridol[2,3- $b][1,4]$ benzodiazepine-6-one base; Thomae, Biberach/Riss, Germany), atropine sulphate (Centrafarm, Etten-Leur, Netherlands), HHSiD ( $p$-fluorohexahydro-siladifenidol hydrochloride; Research Biochemicals International, Natick, MA, USA), McN-A-343 (4-( $m$-chlorophenylcarbamoyloxy)-2-butynyltrimethylammonium chloride; McNiel, Fort Washington, PA, USA), noradrenaline bitartrate (Sigma, St. Louis, MO, USA), physostigmine salicylate (Sandoz, Basel, Switzerland), pirenzepine base (Thomae, Biberach/Riss, Germany), propranolol hydrochloride (Imperial Chemical Industries, Macclesfield, UK).

\section{Results}

\subsection{Viability of the tissues}

The baseline contractile force was significantly lower in the atrial $(97 \pm 13 \mathrm{mg}, n=57)$ than in ventricular $(236 \pm 30 \mathrm{mg}, n=54)$ tissue. In both tissues, nor-
Right atrium

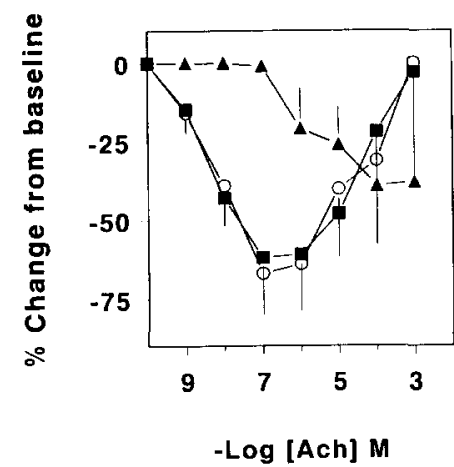

Left ventricle

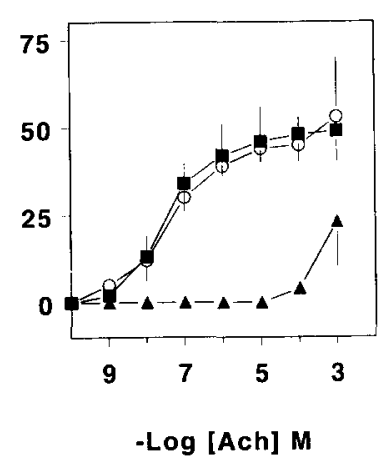

Fig. 1. Cumulative concentration-response curves of acetylcholine (Ach) on the baseline force of contraction, obtained in the atrial (left panel) and ventricular (right panel) trabeculae in the absence $(O$, $n=5$ and 6 , respectively) or presence of $10^{-6} \mathrm{M}$ atropine $(\Delta, n=6$ each) or propranolol ( $\boldsymbol{\square}, n=7$ and 6 , respectively).

adrenaline $\left(10^{-8} \mathrm{M}\right.$ to $\left.10^{-5} \mathrm{M}\right)$ increased contractile force in a concentration-dependent manner. After exposure to $10^{-5} \mathrm{M}$ noradrenaline, the force of contraction went up to $381 \pm 35 \mathrm{mg}(n=57)$ and $627 \pm 65 \mathrm{mg}$ $(n=54)$ in the atrial and ventricular trabeculae, respectively.

\subsection{Inotropic responses to acetylcholine in atrial and ventricular trabeculae}

\section{Effect on the baseline contractility}

The effect of acetylcholine on the baseline atrial and ventricular contractility as well as the influence of atropine and propranolol are shown in Fig. 1. In right atrial trabeculae, acetylcholine exhibited a biphasic contractile response consisting of an initial decrease followed by an increase. At low concentrations $\left(10^{-9}\right.$ to $10^{-7} \mathrm{M}$ ), acetylcholine clearly decreased the baseline contractile force (maximum decrease from baseline values: $67 \pm 13 \%$ at $10^{-7} \mathrm{M}$ ), but with higher concentrations the contractile force started to increase towards baseline values $(0 \pm 23 \%$ change from baseline values at $10^{-3} \mathrm{M}$ ). If after exposure to $10^{-7} \mathrm{M}$ acetylcholine higher concentrations were not used, the contractile force remained depressed without coming back towards baseline values. However, when $10^{-4} \mathrm{M}$ acetylcholine was administrated without the preceding part of the concentration-response curve, no positive inotropic effect was observed (data not shown). In contrast to atria, acetylcholine caused only a positive inotropic effect in left ventricular trabeculae. The maximum increase in contractile force $(53 \pm 17 \%$ from baseline values) was observed at $10^{-3} \mathrm{M}$.

Atropine $\left(10^{-6} \mathrm{M}\right)$ effectively antagonized both the negative and positive inotropic effects of acetylcholine in atrial as well as the positive inotropic effect in 


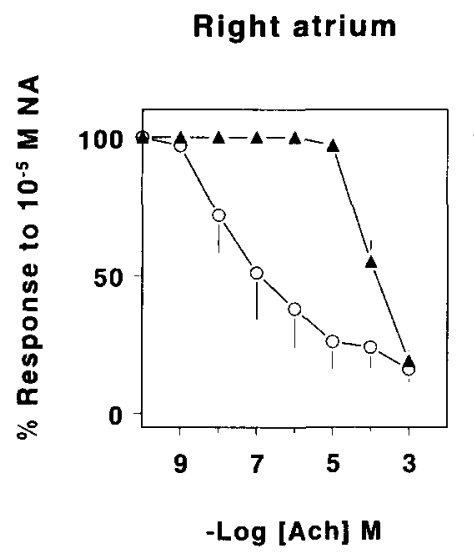

Right atrium

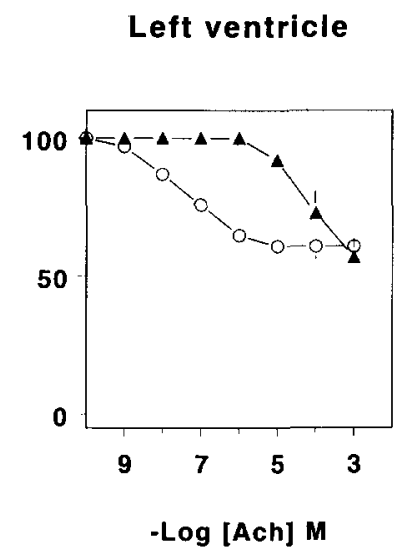

Fig. 2. Cumulative concentration-response curves of acetylcholine (Ach) on force of contraction after pre-stimulation with noradrenaline (NA; $10^{-5} \mathrm{M}$ ), obtained in the atrial (left panel) and ventricular (right panel) trabeculae in the absence $(O, n=7$ and 6 , respectively) or presence of atropine $\left(10^{-6} \mathrm{M} ; \wedge, n=7\right.$ and 5 , respectively).

ventricular trabeculae. Since in the presence of atropine a complete concentration-response curve to acetylcholine could not be constructed, $\mathrm{pD}_{2}$ values of acetylcholine were not calculated. However, from Fig. 1 it can be seen that atropine shifted the concentration-response curve to the right by more than 3 and 4 $\log$ units in atrial and ventricular trabeculae, respectively. Propranolol $\left(10^{-6} \mathrm{M}\right)$ did not modify the responses to acetylcholine.

\section{Effect on noradrenaline-stimulated contractility}

In the presence of noradrenaline $\left(10^{-5} \mathrm{M}\right)$, acetylcholine produced only a negative inotropic effect in both atrial and ventricular trabeculae (Fig. 2). The reduction of the contractile force by $10^{-3} \mathrm{M}$ acetylcholine was from $504 \pm 141$ to $43 \pm 6 \mathrm{mg}(86 \pm 4 \%)$ in atrial trabeculae $(n=7)$ and from $463 \pm 93$ to $288 \pm 59$ $\mathrm{mg}(39 \pm 5 \%)$ in ventricular trabeculae $(n=6)$. The $\mathrm{pD}_{2}$ value for acetylcholine was 7.0 $\pm 0.6(n=5)$ and $6.8 \pm 0.9(n=6)$ in the atrial and ventricular tissues, respectively.

Atropine shifted the concentration-response curve for acetylcholine to the right in both atrial and ventricular tissue following pre-stimulation with $10^{-5} \mathrm{M}$ noradrenaline (Fig. 2). The $\mathrm{pD}_{2}$ values for acetylcholine were decreased in both atrial $(4.5 \pm 0.1 ; n=7)$ and ventricular $(4.8 \pm 0.3 ; n=5)$ trabeculae.

\subsection{Effect of the muscarinic receptor antagonists on acetylcholine-induced inotropic responses}

\section{Right atrium}

Fig. 3 presents concentration-response curves to acetylcholine in atrial trabeculae in the absence (control) or presence of the three relatively selective muscarinic receptor antagonists, whereas the relevant parameters of these curves are summarized in Table 1. The muscarinic $M_{1}$ receptor antagonist pirenzepine $\left(10^{-7}, 10^{-6}\right.$ or $\left.10^{-5} \mathrm{M}\right)$ did not significantly change the negative inotropic effect of acetylcholine $\left(10^{-9}\right.$ to $10^{-6}$ $M)$, whereas the positive inotropic effect of acetylcholine $\left(10^{-6}\right.$ to $\left.10^{-3} \mathrm{M}\right)$ was significantly reduced by pirenzepine at the highest concentration $\left(10^{-5} \mathrm{M} ; \mathrm{p} K_{\mathrm{B}}\right.$ could not be calculated). The muscarinic $\mathbf{M}_{2}$ receptor antagonist AF-DX 116 did not significantly affect the negative inotropic effect of acetylcholine at $10^{-7} \mathrm{M}$, but $10^{-6} \mathrm{M}$ AF-DX 116 produced a parallel shift to the right of the acetylcholine curve (apparent $\mathrm{p} K_{\mathrm{B}}$ : $6.7 \pm 0.4 ; n=8)$ and $10^{-5}$ M AF-DX 116 completely abolished the negative inotropic effect. AF-DX 116 either did not affect $\left(10^{-7}\right.$ and $\left.10^{-6} \mathrm{M}\right)$ or even seemed to increase $\left(10^{-5} \mathrm{M}\right)$ the positive inotropic

Table 1

Maximum negative (with apparent $\mathrm{pD}_{2}$ ) and positive inotropic effects in atrial and maximum positive inotropic effect (with apparent $\mathrm{pD}_{2}$ ) in ventricular trabeculae induced by acetylcholine

\begin{tabular}{|c|c|c|c|c|c|c|c|c|}
\hline \multirow[t]{2}{*}{ Antagonist } & \multirow[t]{2}{*}{$\mu \mathrm{M}$} & \multicolumn{4}{|c|}{ Atrium } & \multicolumn{3}{|c|}{ Ventricle } \\
\hline & & $n$ & Negative $^{a}$ & $\mathrm{pD}_{2}$ & Positive $^{b}$ & $n$ & Positive $^{c}$ & $\mathrm{pD}_{2}$ \\
\hline Control & & 16 & $47 \pm 12$ & $6.8 \pm 0.2$ & $78 \pm 11$ & 14 & $33 \pm 6$ & $5.6 \pm 0.4$ \\
\hline Pirenzepine & 0.1 & 6 & $73 \pm 10$ & $7.1 \pm 0.2$ & $29 \pm 15^{d}$ & 5 & $37 \pm 5$ & $6.3 \pm 0.2$ \\
\hline Pirenzepine & 1 & 8 & $61 \pm 7$ & $6.4 \pm 0.2$ & $37 \pm 11^{d}$ & 4 & $56 \pm 16$ & $5.1 \pm 0.6$ \\
\hline Pirenzepine & 10 & 6 & $58 \pm 6$ & $6.3 \pm 0.2$ & $4 \pm 3^{d}$ & 7 & $50 \pm 20$ & $4.7 \pm 1.8$ \\
\hline Control & & 16 & $66 \pm 5$ & $6.8 \pm 0.2$ & $68 \pm 12$ & 16 & $46 \pm 13$ & $5.8 \pm 0.2$ \\
\hline AF-DX 116 & 0.1 & 6 & $67 \pm 11$ & $6.6 \pm 0.1$ & $50 \pm 23$ & 6 & $38 \pm 9$ & $6.1 \pm 0.1$ \\
\hline AF-DX 116 & 1 & 8 & $57 \pm 20$ & $5.9 \pm 0.2^{d}$ & $47 \pm 37$ & 6 & $26 \pm 11$ & $4.8 \pm 0.6$ \\
\hline AF-DX 116 & 10 & 6 & $\mathrm{~d}, \mathrm{e}^{-}$ & $\mathrm{d}, \mathrm{e}^{-}$ & $111 \pm 51$ & 7 & $29 \pm 12$ & $3.9 \pm 0.1^{d}$ \\
\hline Control & & 10 & $70 \pm 7$ & $7.1 \pm 0.2$ & $75 \pm 30$ & 10 & $36 \pm 6$ & $6.2 \pm 0.3$ \\
\hline HHSiD & 1 & 6 & $69 \pm 6$ & $6.8 \pm 0.1$ & $51 \pm 31$ & 6 & $44 \pm 12$ & $6.0 \pm 0.2$ \\
\hline HHSiD & 10 & 6 & $31 \pm 28^{\mathrm{d}}$ & $6.4 \pm 0.4$ & $106 \pm 57$ & 5 & $32 \pm 10$ & $5.3 \pm 0.4$ \\
\hline
\end{tabular}

a Percent change from baseline values by acetylcholine $\left(10^{-6} \mathrm{M}\right.$ or $10^{-5} \mathrm{M}$ in the presence of the two highest concentrations of pirenzepine); ${ }^{\mathrm{b}}$ percent change by $10^{-3} \mathrm{M}$ acetylcholine, calculated as the difference from the maximal negative effect $\left(\mathrm{pD}_{2}\right.$ not calculable); ${ }^{\mathrm{c}}$ percent change from baseline values by acetylcholine $\left(10^{-4} \mathrm{M}\right.$ or $\left.10^{-3} \mathrm{M}\right) ;{ }^{d}$ significantly different from values in control experiments run in parallel; ${ }^{c}$ only positive inotropic response. 


\section{Right atrium}

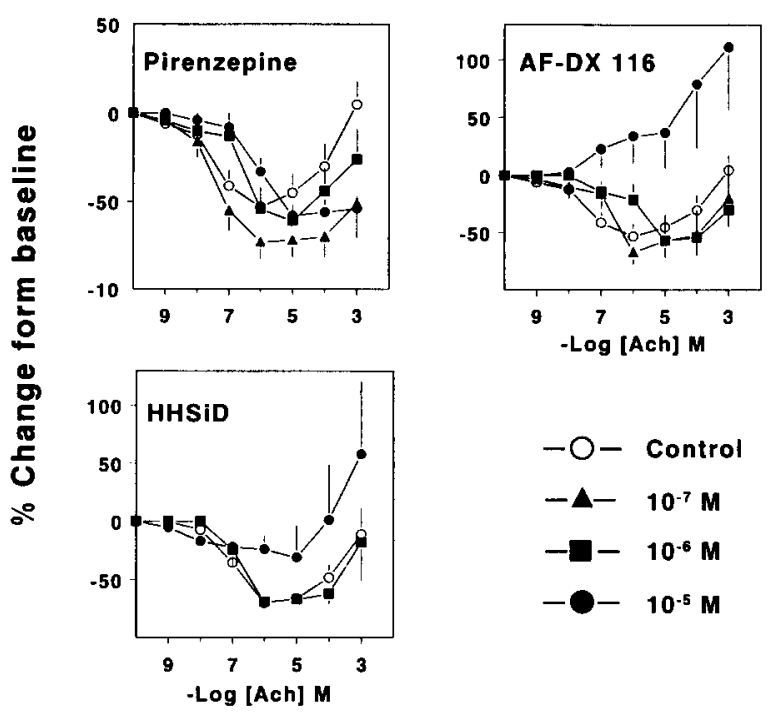

Fig. 3. Cumulative concentration-response curves of acetylcholine (Ach) on baseline force of contraction in the atrial trabeculae in the absence or presence of antagonists. Upper left panel: acetylcholine alone $(n=16)$ or in the presence of pirenzepine $\left(10^{-7}, 10^{-6}\right.$ and $10^{-5} \mathrm{M} ; n=6,8$ and 6 , respectively). Upper right panel: acetylcholine alone $(n=16)$ or in the presence of AF-DX $11610^{-7}, 10^{-6}$ and $10^{-5} \mathrm{M} ; n=6,8$ and 6 , respectively). Lower left panel: acetylcholine alone $(n=10)$ or in the presence of HHSiD $\left(10^{-6}\right.$ and $10^{-5}$ $\mathrm{M} ; n=6$ each).

component of the effects of acetylcholine. The preferential muscarinic $\mathrm{M}_{3}$ receptor antagonist HHSiD $\left(10^{-6}\right.$ M) failed to modify the effects of acetylcholine, but its higher concentration $\left(10^{-5} \mathrm{M}\right)$ reduced the negative inotropic component (apparent $\mathrm{p} K_{\mathrm{B}}: 6.0 \pm 0.6 ; n=6$ ), without affecting the positive inotropic component.

\section{Left ventricle}

The effects of muscarinic receptor antagonists on acetylcholine-induced positive inotropic effects in ventricular trabeculae are shown in Fig. 4 and Table 1. Pirenzepine did not efficiently antagonize the responses to acetylcholine; only at $10^{-5} \mathrm{M}$ pirenzepine, the curve for the acetylcholine seemed to be slightly shifted to the right (apparent $\mathrm{p} K_{\mathrm{B}}: 5.7 \pm 0.5 ; n=6$ ). On the other hand, AF-DX $116\left(10^{-6}\right.$ and $\left.10^{-5} \mathrm{M}\right)$ caused a concentration-dependent antagonism of the responses to acetylcholine (apparent $\mathrm{p} K_{\mathrm{B}}: 6.7 \pm 0.6$ and $6.2 \pm 0.3$, respectively; $n=6$ each). HHSiD failed to modify the responses to acetylcholine.

\subsection{Effects of $M c N-A-343$}

\section{Baseline contractility}

The effects of McN-A-343 $\left(10^{-9}\right.$ to $\left.10^{-3} \mathrm{M}\right)$, a relatively selective muscarinic $\mathbf{M}_{1}$ receptor agonist, on the baseline contractility in the atrial and ventricular trabeculae are presented in Fig. 5. McN-A-343 failed to significantly alter the force of contraction in either

\section{Left ventricle}
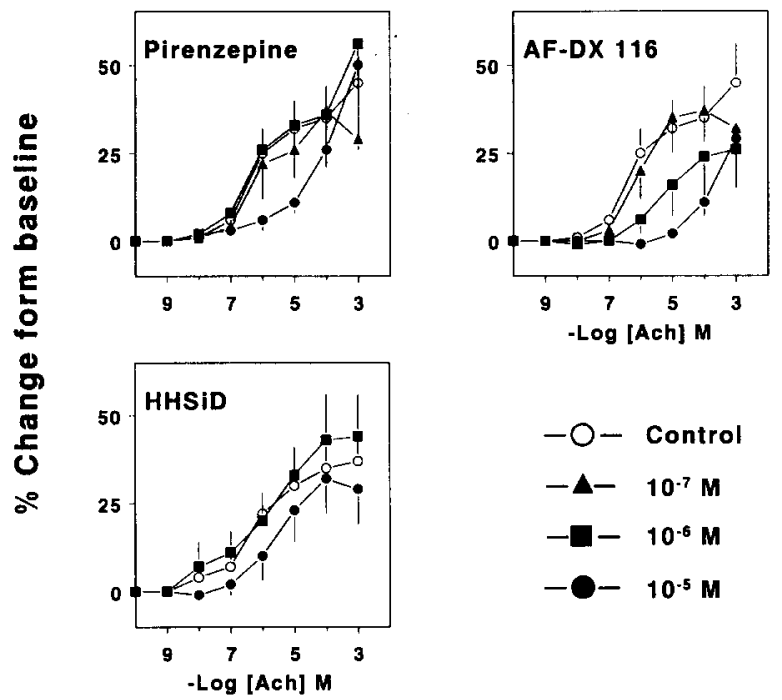

-O- Control

$-\Delta-10^{-7} \mathrm{M}$

$-\square-10^{-6} \mathrm{M}$

$-10^{-5} \mathrm{M}$

Fig. 4. Cumulative concentration-response curves of acetylcholine (Ach) on baseline force of contraction in the ventricular trabeculae in the absence or presence of antagonists. Upper left panel: acetylcholine alone $(n=14)$ or in the presence of pirenzepine $\left(10^{-7}, 10^{-6}\right.$ and $10^{-5} \mathrm{M} ; n=5,4$ and 7 , respectively). Upper right panel: acetylcholine alone $(n=16)$ or in the presence of AF-DX $11610^{-7}$, $10^{-6}$ and $10^{-5} \mathrm{M} ; n=6,6$ and 7 , respectively). Lower left panel: acetylcholine alone $(n=10)$ or in the presence of HHSiD $\left(10^{-6}\right.$ and $10^{-5} \mathrm{M} ; n=6$ and 5 , respectively).

tissue; the values before and after McN-A-343 $\left(10^{-3}\right.$ M) were $230 \pm 51$ and $208 \pm 56 \mathrm{mg}$ in atrial trabeculae and $348 \pm 139$ and $358 \pm 130 \mathrm{mg}$ in ventricular trabeculae.

\section{Acetylcholine-induced depressed contractility in atrial} trabeculae

Fig. 6 presents examples of original tracings showing the effects of acetylcholine and McN-A-343 in atrial

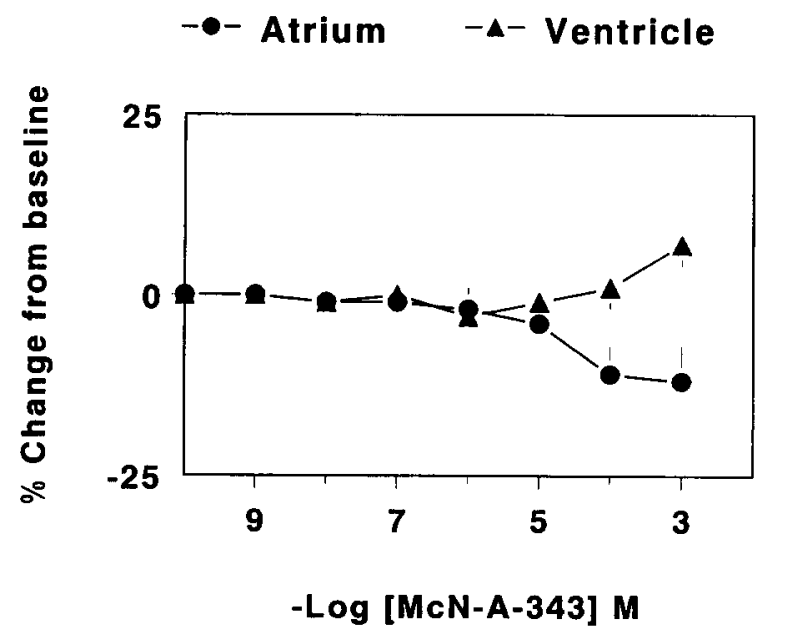

Fig. 5. Cumulative concentration-response curves of McN-A-343 on baseline force of contraction, obtained in atrial (•) and ventricular (৯) trabeculae $(n=6$ each). 
trabeculae. Acetylcholine $\left(10^{-7} \mathrm{M}\right)$ produced a sustained negative inotropic effect (panel A), which was reversed by higher concentrations of acetylcholine $(>$ $10^{-6} \mathrm{M}$; panel B) as well as by McN-A-343 ( $\geq 10^{-8} \mathrm{M}$; panel C). Pre-treatment of the atrial trabeculae with pirenzepine $\left(10^{-5} \mathrm{M}\right)$ antagonized the positive inotropic effect of McN-A-343 (panel D).

The mean data obtained in atrial trabeculae with McN-A-343 in the absence or presence of $10^{-5} \mathrm{M}$ pirenzepine (after maximum negative inotropic effect was reached by low concentrations of acetylcholine) are presented in Fig. 7. Acetylcholine decreased the baseline contractile force from $868 \pm 169 \mathrm{mg}$ to $140 \pm$ $63 \mathrm{mg}(-84 \pm 5 \%)$ at $10^{-7} \mathrm{M}(n=5)$. McN-A-343 $\left(10^{-9}\right.$ to $\left.10^{-3} \mathrm{M}\right)$ increased the contractile force back to baseline values $\left(902 \pm 170 \mathrm{mg}\right.$ at $\left.10^{-3} \mathrm{M} ; n=5\right)$ in a concentration-dependent way $\left(\mathrm{pD}_{2}: 6.75 \pm 0.42\right)$. Although pirenzepine $\left(10^{-5} \mathrm{M}\right)$ slightly shifted the acetylcholine curve to the right, it strongly antagonized the $\mathrm{McN}-\mathrm{A}-343$-induced positive inotropic effect. In the presence of pirenzepine, the force of contraction was not changed by McN-A-343 $\left(10^{-9}\right.$ to $\left.10^{-4} \mathrm{M}\right)$. Only at $10^{-3} \mathrm{M}, \mathrm{McN}-\mathrm{A}-343$ increased the contractility from $67 \pm 17$ to $285 \pm 42 \mathrm{mg}$, close to baseline values

A

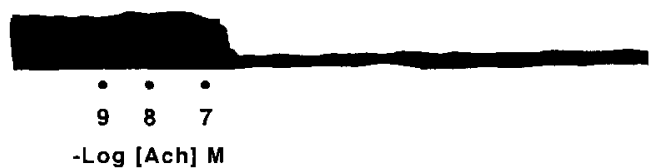

$\mathbf{B}$

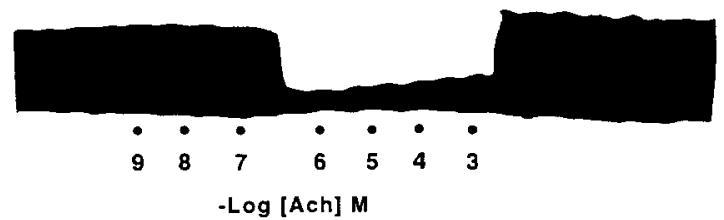

C

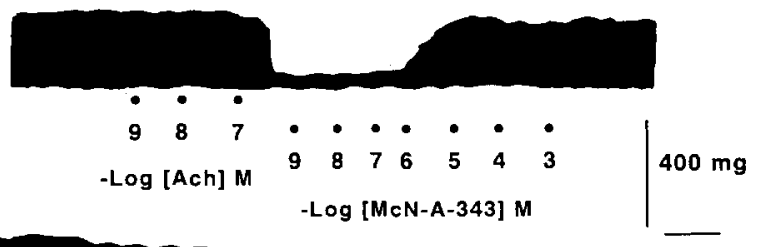

D

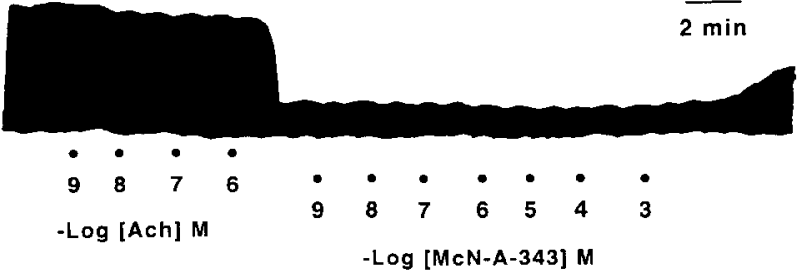

Fig. 6. Recordings of force of contraction in four right atrial trabeculae showing the effects of acetylcholine (Ach) in different concentrations. Note that the negative inotropic effect of acetylcholine $\left(10^{-7}\right.$ $M$ ), which was maintained for several min (panel A), was reversed by higher concentrations of acetylcholine (panel B) and McN-A-343 (panel C). The reversal of the negative inotropic effect of acetylcholine by $\mathrm{McN}-\mathrm{A}-343$ was not observed in atrial trabeculae pretreated with pirenzepine $\left(10^{-5} \mathrm{M}\right)$ (panel D).

\section{Atrium}

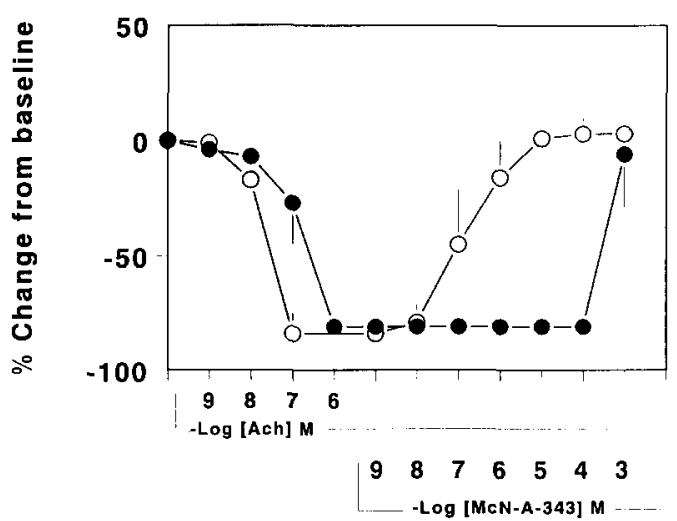

Fig. 7. Cumulative concentration-response curves of $\mathrm{McN}-\mathrm{A}-343$ on the force of contraction in atrial trabeculae after depression of contractility by acetylcholine (Ach; $10^{-9}$ to $10^{-7}$ or $10^{-6} \mathrm{M}$ ), obtained in the absence $(O ; n=5)$ or presence $(\bullet ; n=4)$ of pirenzepine $\left(10^{-5} \mathrm{M}\right)$.

$(380 \pm 110 \mathrm{mg})(n=4)$; the $\mathrm{pD}_{2}$ value of $\mathrm{McN}-\mathrm{A}-343$ based on the last response was $3.56 \pm 0.06$. The apparent $\mathrm{p} K_{\mathrm{B}}$ value of pirenzepine against $\mathrm{McN}-\mathrm{A}-343$ was found to be $8.57 \pm 0.33(n=4)$.

\section{Discussion}

\subsection{Involvement of the muscarinic receptors in acetyl- choline-induced responses}

The results from the present and previous ( $\mathrm{Du}$ et al., 1994) studies show that in the human isolated myocardium acetylcholine elicits complex inotropic effects, consisting of a biphasic response (decrease followed by increase at high concentrations) in the atrial baseline contractility and only an increase in the ventricular baseline contractility. However, in conformity with previous observations (Jakob et al., 1989; Deighton et al., 1990; Böhm et al., 1994) in the isoprenaline-augmented human isolated myocardium, acetylcholine decreased contractility in both atrial and ventricular preparations after prior exposure to noradrenaline. The negative inotropic effect of muscarinic cholinergic agents (antagonized by atropine) is well known, but their positive inotropic action, though reported in some animal species (rat atria, Imai and Ohta, 1982; guineapig papillary muscles, Korth and Kühlkamp, 1987; guinea-pig atria, Eglen et al., 1988; chick ventricles, Tsuji et al., 1987), has not been reported in humans (see Jakob et al., 1989; Deighton et al., 1990; Böhm et al., 1994). The reasons for this discrepancy are not entirely clear. However, in contrast to our investigations performed in non-diseased hearts and with acetylcholine in ventricular trabeculae, previous au- 
thors (Jakob et al., 1989; Deighton et al., 1990; Böhm et al., 1994) studied the effects of carbachol on papillary muscles obtained from hearts removed from patients undergoing heart transplantation surgery.

The precise receptor mechanisms involved in the positive inotropic effects of muscarinic cholinergic agents are not well understood. In the rat atria (Imai and Ohta, 1982), guinea-pig papillary muscle (Korth and Kühlkamp, 1987) and chick ventricles (Tsuji et al., 1987), the positive inotropic effect was antagonized by atropine and, in the last two tissues, it was also shown that the effect, being unaffected by prior reserpinization (Korth and Kühlkamp, 1987) or propranolol (Tsuji et al., 1987), was independent of endogenous catecholamines. In accordance with these observations, we also found that atropine not only blocked the negative inotropic effect in the atria, but also the positive inotropic responses in both atria and ventricles; these responses remained unaltered after exposure to propranolol. Thus, the results show that both the negative and positive inotropic effects of acetylcholine in the human isolated myocardium are mediated by muscarinic receptors.

\subsection{Subtypes of muscarinic receptors involved in acetyl- choline responses}

Although, at present, highly selective antagonists at muscarinic receptors are not available, a combination of relatively selective antagonists can be employed to characterize the muscarinic receptor subtypes. In the present investigation, we used three such antagonists having different selectivity profiles, namely pirenzepine $\left(\mathbf{M}_{1}>\mathbf{M}_{3}>\mathbf{M}_{2}\right)$, AF-DX $116\left(\mathbf{M}_{2}>\mathbf{M}_{1}>\mathbf{M}_{3}\right)$ and HHSiD $\left(M_{3} \geq M_{1} \gg M_{2}\right)$ (Doods et al., 1994). However, it should be pointed out that the affinity values of these relatively selective antagonists obtained in the present experiments in the human myocardium are further prejudiced by the complex nature of acetylcholine responses.

\section{Involvement of the muscarinic $M_{2}$ receptor subtype}

The present study showed that AF-DX 116 most effectively antagonized the atrial negative inotropic (Fig. 3) and ventricular positive inotropic (Fig. 4) effects of acetylcholine; the concentration-response curves were clearly shifted to the right. The calculated apparent $\mathrm{p} K_{\mathrm{B}}$ values of AF-DX 116 in the atria (6.7 \pm $0.4)$ and ventricles $(6.7 \pm 0.6)$ against the negative and positive inotropic responses, respectively, to acetylcholine reasonably match with its $\mathrm{p} K_{\mathrm{i}}$ values $(7.14 \pm$ 0.06 and $7.18 \pm 0.06$, respectively) in the two tissues for the displacement of $\left[{ }^{3} \mathrm{H}\right] \mathrm{N}$-methyl scopolamine in guinea-pig membranes (Michel and Whiting, 1987). Thus, it appears that the muscarinic $\mathbf{M}_{2}$ receptor subtype mediates both the negative (in atria) and positive (in ventricles) inotropic responses. This conclusion is in agreement with the demonstration of the muscarinic $\mathrm{M}_{2}$ receptor mRNA and protein in the human heart (Maeda et al., 1988; Caulfield, 1993). Moreover, it is now well established that muscarinic $\mathrm{M}_{2}$ receptors are coupled to three signal transduction pathways (Schimerlik, 1989): (i) inhibition of adenylyl cyclase to reduce cAMP (Fleming et al., 1987), (ii) opening of potassium channels (Ray and MaCleod, 1993), and (iii) hydrolysis of phosphatidylinositol. The first two may contribute to the negative inotropic response associated with muscarinic receptor stimulation (Hanf et al., 1993), while the third may induce positive inotropic responses (Mizushima et al., 1987; Kohl et al., 1990). Although the exact molecular processes are unclear, it is believed that the two opposite functional responses are mediated via muscarinic $\mathrm{M}_{2}$ receptors coupled to different G-proteins and occurring in different affinity states: a high affinity state associated with inhibition of adenylyl cyclase and a low affinity state associated with the phosphatidylinositol breakdown (Brown and Brown, 1984).

A recent study comparing muscarinic $\mathrm{K}^{+}$channels in the human atrium and ventricle (Koumi and Wasserstrom, 1994) showed that the acetylcholine-induced $\mathrm{K}^{+}$ current in whole cell preparations from the two tissues exhibited essentially similar characteristics, except with regard to the channel density. Acetylcholine-induced $\mathrm{K}^{+}$current in atria was approximately 2-3 times higher than that in ventricles. Another study on the comparison of coupling of muscarinic receptors in guinea-pig atrial and ventricular myocardium showed that atrial and ventricular receptors were similar, but receptor coupling to cyclase inhibition or phosphatidylinositol hydrolysis was distinguishable (Woodcock et al., 1987). Thus, it is possible that all three pathways operate to mediate the observed tissue responses, but their importance may vary in different tissues and/or conditions. Based on the effect of acetylcholine on the baseline contractility (without prior stimulation with, for example, noradrenaline), it would appear that the coupling of the muscarinic $\mathrm{M}_{2}$ receptors to adenylyl cyclase (negatively) and $\mathrm{K}^{+}$channels may be more important in the atrial tissue, whereas in the ventricular tissue the muscarinic $\mathbf{M}_{2}$ receptors probably couple preferentially to phosphatidylinositol hydrolysis. However, it is possible that the coupling can alter in different conditions. Indeed, it is interesting to recall that in the human ventricular myocardium a concentration-dependent negative inotropic effect was seen after pre-stimulation with sympathomimetic agents (Jakob et al., 1989; Landzberg et al., 1994; present results).

\section{Involvement of the muscarinic $M_{1}$ receptor subtype}

Experiments with AF-DX 116 and HHSiD in atrial tissue showed that the positive inotropic effect of 
acetylcholine, observed with high concentrations and only when the atrial contractility had been depressed, was not attenuated and seemed to be potentiated by these compounds, apparently due to the elimination of the negative inotropic effect. On the other hand, pirenzepine seemed to attenuate this response, thereby accentuating the preceding negative inotropic effect (Fig. 3). It therefore appears that the acetylcholine-induced increase in depressed contractility is mediated by the muscarinic $M_{1}$ receptor subtype rather than the $M_{2}$ or $\mathrm{M}_{3}$ subtype. Although HHSiD has been reported to be a more potent antagonist against $M_{1}$ than $M_{2}$ receptors (see Doods et al., 1994), this apparently does not seem to hold true for the human heart, where this compound blocked $\mathrm{M}_{2}$ receptor mediated responses (negative inotropism in atria and positive inotropism in ventricles) more effectively.

The conclusion that the muscarinic $M_{1}$ receptor subtype mediates acetylcholine-induced increases in atrial contractility is further substantiated by the results obtained with McN-A-343, which in the radioligand binding assays has similar affinities for the muscarinic $M_{1}$ and $M_{2}$ receptor subtypes, but in functional assays, probably due to differences in intrinsic efficacy and/or tissue receptor reserve, shows selectivity for the muscarinic $M_{1}$ receptor subtype (Eglen et al., 1987). Indeed, McN-A-343 failed to decrease atrial or increase ventricular contractility (Fig. 5), thus ruling out the activation of muscarinic $\mathrm{M}_{2}$ receptor subtype in the human heart. This compound, however, mimicked acetylcholine (higher concentrations) in increasing atrial contractility, once this had been depressed by prior administration of low concentrations of acetylcholine (Fig. 6). The reversal of the negative inotropic effect of acetylcholine by McN-A-343 cannot be due to a blockade of muscarinic $M_{2}$ receptors, since the effect of McN-A-343 was antagonized by pirenzepine. The apparent $\mathrm{p} K_{\mathrm{B}}$ value of pirenzepine against McN-A-343 $(8.57 \pm 0.33)$ was similar to the binding affinity of the drug at the human cloned muscarinic $M_{1}$ receptor ( $\mathrm{p} K_{\mathrm{i}}: 8.20 \pm 0.13$; Dorje et al., 1991), thus confirming the involvement of muscarinic $M_{1}$ receptor subtype. Additional evidence for functional atrial muscarinic $\mathbf{M}_{1}$ receptors comes from studies of Pitschner and Wellstein (1988), who observed that low doses $(<3 \mathrm{mg})$ of pirenzepine decrease heart rate in human subjects. Similarly, the bradycardia caused by low doses of atropine in humans may also be related to blockade of muscarinic $\mathbf{M}_{1}$ receptors (Wellstein and Pitschner, 1988; present results), rather than central vagal stimulation (Weiner, 1990).

Kellar et al. (1985) examined the binding of $\left[{ }^{3} \mathrm{H}\right]$ acetylcholine and suggested that most of the muscarinic $\mathbf{M}_{2}$ sites had a high affinity for acetylcholine, whereas the majority of muscarinic $\mathbf{M}_{1}$ sites had a low affinity for acetylcholine. This is in agreement with our observations that the positive inotropic response in the atrial trabeculae was obtained with high concentrations of acetylcholine $\left(10^{-4}\right.$ or $\left.10^{-3} \mathrm{M}\right)$. It is possible that the muscarinic $M_{1}$ receptors mediating increases in atrial contractility are coupled to phosphatidylinositol hydrolysis (Gallo et al., 1993; Wess, 1993).

In conclusion, the present investigation in the human isolated myocardium showed that: (i) in addition to the generally accepted negative inotropic effect, acetylcholine also causes positive inotropic effects at similar concentrations in human ventricular trabeculae and these negative and positive inotropic responses are mediated by the muscarinic $M_{2}$ receptor subtype, possibly having preferential coupling to adenylyl cyclase (negatively) and $\mathrm{K}^{+}$channels in atria, and to phosphoinositol breakdown in ventricles, (ii) in trabeculae prestimulated with noradrenaline, acetylcholine elicited negative inotropic responses in both atrial and ventricular trabeculae, suggesting that the preferential coupling in the ventricles can be altered, and (iii) when atrial contractility has already been depressed, high concentrations of acetylcholine as well as McN-A-343 can increase the atrial contractility back towards baseline values via the muscarinic $\mathbf{M}_{1}$ receptor subtype. The physiological relevance of the atrial muscarinic $\mathbf{M}_{1}$ receptor is not yet clear.

\section{References}

Böhm, M., P. Gierschik, R.H.G. Schwinger, R. Uhlmann and E. Erdmann, 1994, Coupling of $M$-cholinoceptors and $A_{1}$ adenosine receptors in human myocardium, Am. J. Physiol. 266, H1951.

Brodde, O.-E., A. Broede, A. Daul, K. Kunde and M.C. Michel, 1992, Receptor systems in the non-failing human heart, Basic Res. Cardiol. 87 (Suppl.), 1.

Brown, J.H. and S.L. Brown, 1984, Agonists differentiate muscarinic receptors that inhibit cyclic AMP formation from those that stimulate phosphoinositide metabolism, J. Biol. Chem. 259, 3777.

Caulfield, M.P., 1993, Muscarinic receptor - characterization, coupling and function, Pharmacol. Ther. 58, 319.

Chatonnet, A. and O. Lockridge, 1989, Comparison of butyrylcholinesterase and acetylcholinesterase, Biochem. J. 260, 625.

Deighton, N.M., S. Motomura, D. Borquez, H.-R. Zerkwoski, N. Doetsch and O.-E. Brodde, 1990, Muscarinic cholinoceptors in the human heart: demonstration, subclassification, and distribution, Naunyn-Schmied. Arch. Pharmacol. 341, 14.

De Lean, D.A., P.J. Munson and D. Rodbard, 1978, Simultaneous analysis of families of sigmoidal curves: application to bioassay, radioligand assay, and physiological dose-response curves, Am. J. Physiol. 235, E97.

Doods, H.N., M.J. Mathy, D. Davidesko, K.J. Van Charldorp, A. De Jonge and P.A. Van Zwieten, 1987, Selectivity of muscarinic antagonists in radioligand and in vivo experiments for the putative $\mathbf{M}_{1}, \mathbf{M}_{2}$ and $\mathbf{M}_{3}$ receptors, J. Pharmacol. Exp. Ther. 242, 257.

Doods, H.N., M. Entzeroth, H. Ziegler, N. Mayer and P. Holzer, 1994, Pharmacological profile of selective muscarinic receptor antagonists on guinea-pig ileal smooth muscle, Eur. J. Pharmacol. $253,275$. 
Dorje, F., J. Wess, G. Lambrecht, R. Tacke, E. Mutschler and M.R. Brann, 1991, Antagonist binding profiles of five cloned human muscarinic receptor subtypes, J. Pharmacol. Exp. Ther. 256, 727.

Du, X.Y., R.G. Schoemaker, W.A. Bax, E. Bos and P.R. Saxena, 1993, Effects of histamine on porcine isolated myocardium: differentiation from effects on human tissue, J. Cardiovasc. Pharmacol. $22,468$.

Du, X.Y., R.G. Schoemaker, E. Bos and P.R. Saxena, 1994, Different pharmacological responses of atrium and ventricle: studies with human cardiac tissue, Eur. J. Pharmacol. 259, 173.

Du, X.Y., R.G. Schoemaker, E. Bos and P.R. Saxena, 1995, Characterization of the positive and negative inotropic effects of acetylcholine in the human isolated atrial and ventricular trabeculae, Br. J. Pharmacol. (in press).

Eglen, R.M., B.A. Kenny, A.D. Michel and R.L. Whiting, 1987, Muscarinic activity of McN-A-343 and its value in muscarinic receptor classification, Eur. J. Pharmacol. 290, 693.

Eglen, R.M., W.W. Montgomery and R.L. Whiting, 1988, Negative and positive inotropic responses to muscarinic agonists in guinea pig and rat atria in vitro, J. Pharmacol. Exp. Ther. 247, 911.

Endoh, M. and J.R. Blinks, 1984, Effects of endogenous neurotransmitters on calcium transients in mammalian atrial muscle, in: Neuronal and Extraneuronal Events in Autonomic Pharmacology, eds. W.W. Fleming, K.H. Graefe, S.Z. Langer and N. Weiner (Raven Press, New York), p. 221.

Evans, R.A., M. Watson, H.I. Yamamura and W.R. Roeske, 1985, Differential ontogeny of putative $M_{1}$ and $M_{2}$ muscarinic receptor binding sites in the murine cerebral cortex and heart, J. Pharmacol. Exp. Ther. 235, 612.

Fleming, J.W., R.A. Strawbridge and M. Watanabe, 1987, Muscarinic receptor regulation of cardiac adenylate cyclase activity, J. Mol. Cell Cardiol. 19, 47

Ford, A.P.D.W., R.M. Eglen and R.L. Whiting, 1992, Analysis of muscarinic cholinoceptors mediating phosphoinositide hydrolysis in guinea pig cardiac muscle, Eur. J. Pharmacol. 225, 105.

Gallo, M.P., G. Alloatti, C. Eva, A. Oberto and R.C. Levi, 1993, M $_{1}$ muscarinic receptors increase calcium current and phosphoinositide turnover in guinea-pig ventricular cardiocytes, J. Physiol. 471, 41.

Giachetti, A., R. Micheletti and E. Montagna, 1986, Cardioselective profile of AF-DX 116, a muscarine $\mathbf{M}_{2}$ receptor antagonist, Life Sci. $38,1663$.

Hammer, R., C.P. Berrie, N.J.M. Birdsall, A.S.V. Burgen and E.C. Hulme, 1980, Pirenzepine distinguishes between different subclasses of muscarinic receptors, Nature 283, 90.

Hanf, R., Y.X. Li, G. Szabo and R. Fischmeister, 1993, Agonist-independent effects of muscarinic antagonists on $\mathrm{Ca}^{2+}$ and $\mathrm{K}^{+}$ current in frog and rat cardiac cells, J. Physiol. 461, 743.

Imai, S. and H. Ohta, 1982, Positive inotropic effects induced by carbachol in rat atria treated with islet-activating protein (IAP) association with phosphatidylinositol breakdown, $\mathrm{Br}$. J. Pharmacol. 94, 347.

Jakob, H., H. Oelert, J. Rupp and H. Nawrath, 1989, Functional role of cholinoceptors and purinoceptors in human isolated ventricular heart muscle, Br. J. Pharmacol. 97, 1199.

Kellar, K.J., A.M. Martino, D.P. Hall, R.D. Schwartz and R.L. Taylor, 1985, High-affinity binding of $\left[{ }^{3} \mathrm{H}\right]$ acetylcholine to muscarinic cholinergic receptors, J. Neurosci. 5, 1577.

Kohl, C., W. Schmitz and H. Scholz, 1990, Positive inotropic effect of carbachol and inositol phosphate levels in mammalian atria after pretreatment with pertussis toxin, J. Pharmacol. Exp. Ther. 254, 894.

Korth, M. and V. Kühlkamp, 1987, Muscarinic receptors mediate negative and positive inotropic effects in mammalian ventricular myocardium: differentiation by agonists, Br. J. Pharmacol. 90, 81.

Koumi, S.I. and J.A. Wasserstrom, 1994, Acetylcholine-sensitive muscarinic $\mathrm{K}^{+}$channels in mammalian ventricular myocytes, Am. J. Physiol. 266, H1812.

Lambrecht, G., R. Feifel, U. Moster, M. Wagner-Roder, L.K. Choo, J. Camus, M. Tastenoy, M. Waelbroeck, C. Strohmann, R. Tacker, J.F. Miranda, J. Christophe and E. Mutschler, 1989, Pharmacology of hexahydro-difenidol, hexahydro-sila-difenidol and related selective muscarinic antagonists, Trend Pharmacol. Sci. 10 (Suppl.), 60.

Landzberg, J.S., J.D. Parker, D.F. Gauthier and W.S. Colucci, 1994, Effects of intracoronary acetylcholine and atropine on basal and dobutamine-stimulated left ventricular contractility, Circulation 89, 164.

Maeda, A., T. Kubo, M. Mishina and S. Numa, 1988, Tissue distribution of mRNAs encoding muscarinic acetylcholine receptor subtypes, FEBS Lett. 239, 339.

Michel, A.D. and R.L. Whiting, 1987, Direct binding studies on ileal and cardiac muscarinic receptors, Br. J. Pharmacol. 92, 755.

Mizushima, A., S. Uchida, X.M. Zhou, T. Kagiya and H. Yoshida, 1987, Cardiac $M_{2}$ receptors consist of two different types, both regulated by GTP, Eur. J. Pharmacol. 135, 403.

Pitschner, H.F. and A. Wellstein, 1988, Dose-response curves of pirenzepine in man in relation to $\mathbf{M}_{1}$ and $\mathbf{M}_{2}$-cholinoceptor occupancy. Naunyn-Schmied. Arch. Pharmacol. 338, 207.

Ploeg, R.J., J.H. Van Bockel, P.T.H. Langendijk, M. Groenewegen, F.J. Van der Woude, G.G. Persijn, J. Thorogood and J. Hermans, 1992, Effect of preservation solution on results of cadaveric kidney transplantation, Lancet 340, 129.

Ray, A. and K.M. MaCleod, 1993, A pharmacological investigation of the contribution of muscarinic receptor-linked potassium channels to the reversal by carbachol of positive inotropic responses of rabbit left atrium to cyclic AMP-generating agents, J. Pharmacol. Exp. Ther. 266, 1594.

Rosen, M.R., S.F. Steinberg and P. Danilo, 1990, Developmental changes in the muscarinic stimulation of canine Purkinje fibers, $J$. Pharmacol. Exp. Ther. 254, 356.

Schimerlik, M.I., 1989, Structure and regulation of muscarinic receptors, Annu. Rev. Physiol. 51, 217.

Schoemaker, R.G., X.Y. Du, W.A. Bax, E. Bos and P.R. Saxena, 1993, 5-Hydroxytryptamine stimulates human isolated atrium but not ventricle, Eur. J. Pharmacol. 230, 103.

Tajima, T., Y. Tsuji, S. Sorota and A.J. Pappano, 1987, Positive vs. negative inotropic effects of carbachol in avian atrial muscle: role of $\mathrm{N}_{\mathrm{i}}$ like protein, Circ. Res. 61 (Suppl. 1), I-105.

Tsuji, Y., T. Tajima, J. Yuen and A.J. Pappano, 1987, Positive inotropic effects of acetylcholine and BAY K 8644 in embryonic chick ventricle, Am. J. Physiol. 252, H807.

Watson, M., H.I. Yamamura and W.R. Roeske, 1983, A unique regulatory profile and regional distribution of $\left[{ }^{3} \mathrm{H}\right]$ pirenzepine binding in the rat provides evidence for distinct $M_{1}$ and $M_{2}$ muscarinic receptor subtypes, Life Sci. 32, 3001.

Weiner, N., 1990, Atropine, scopolamine, and related antimuscarinic drugs, in: Goodman and Gilman's The Pharmacological Basis of Therapeutics, eds. A. Goodman Gilman, T.W. Rall, A.S. Nies and P. Taylor (Macmillan Publishing Company, New York) p. 150.

Wellstein, A. and H.F. Pitschner, 1988, Complex dose-response curves of atropine in man explained by different functions of $M_{1}$ and $\mathrm{M}_{2}$-cholinoceptors, Naunyn-Schmied. Arch. Pharmacol. 338, 19.

Wess, J., 1993, Molecular basis of muscarinic acetylcholine receptor function, Trends Pharmacol. Sci. 14, 308.

Woodcock, E.A., E. Leung and J.K. Mcleod, 1987, A comparison of muscarinic acetylcholine receptors coupled to phosphatidylinositol turnover and to adenylate cyclase in guinea-pig atria and ventricles, Eur. J. Pharmacol. 133, 283. 